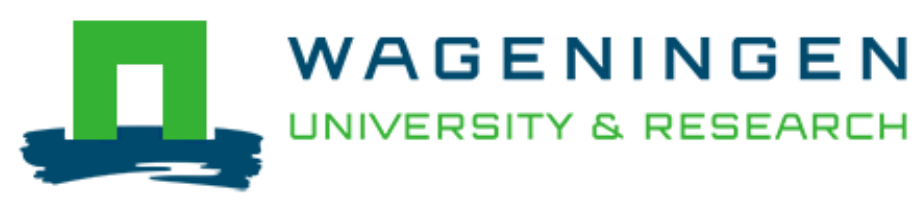

\title{
Reducing Sediment Connectivity Through man-Made and Natural Sediment Sinks in the Minizr Catchment, Northwest Ethiopia
}

\author{
Mekonnen, M., Keesstra, S. D., Baartman, J. E. M., Stroosnijder, L., \& \\ Maroulis, J.
}

This article is made publically available in the institutional repository of Wageningen University and Research, under article 25fa of the Dutch Copyright Act, also known as the Amendment Taverne.

Article $25 \mathrm{fa}$ states that the author of a short scientific work funded either wholly or partially by Dutch public funds is entitled to make that work publicly available for no consideration following a reasonable period of time after the work was first published, provided that clear reference is made to the source of the first publication of the work.

For questions regarding the public availability of this article, please contact openscience.library@wur.nl.

Please cite this publication as follows:

Mekonnen, M., Keesstra, S. D., Baartman, J. E. M., Stroosnijder, L., \& Maroulis, J. (2017). Reducing Sediment Connectivity Through man-Made and Natural Sediment Sinks in the Minizr Catchment, Northwest Ethiopia. Land Degradation and Development, 28(2), 708-717. https://doi.org/10.1002/ldr.2629 


\title{
REDUCING SEDIMENT CONNECTIVITY THROUGH MAN-MADE AND NATURAL SEDIMENT SINKS IN THE MINIZR CATCHMENT, NORTHWEST ETHIOPIA
}

\author{
Mulatie Mekonnen ${ }^{1,2 *}$, Saskia D. Keesstra ${ }^{1}$, Jantiene E. M. Baartman ${ }^{1}$, Leo Stroosnijder ${ }^{1}$, Jerry Maroulis ${ }^{1,3}$ \\ ${ }^{1}$ Soil Physics and Land Management Group, Wageningen University, P O Box 47, 6700 AA Wageningen, The Netherlands \\ ${ }^{2}$ Amhara National Regional State, Bureau of Agriculture, P O Box 1188, Bahir Dar, Ethiopia \\ ${ }^{3}$ International Centre for Applied Climate Sciences, University of Southern Queensland, Toowoomba QLD 4350, Australia
}

Received 7 April 2016; Revised 19 July 2016; Accepted 19 July 2016

\begin{abstract}
Man-made and natural sediment sinks provide a practical means for reducing downstream reservoir sedimentation by decreasing soil erosion and enhancing the rate of sedimentation within a catchment. The Minizr catchment $\left(20 \mathrm{~km}^{2}\right)$ in the northwest Ethiopian highlands contains numerous man-made soil and water conservation (SWC) structures such as soil bunds (Erken), fanya juu ridge (Cab) and micro-trenches and natural sediment sinks such as wetlands, floodplains and grassed waterways. These sediment sinks reduce downstream sedimentation into the Koga reservoir, located at the catchment outlet, however, a large quantity of sediment is still reaching the reservoir. This study evaluates the function and effectiveness of both man-made SWC structures and natural sediment sinks in reducing sediment export from the Minizr catchment. SWC structures and natural sediment sinks were digitized using Google Earth Imagery. Sediment pins and vertical sampling through the deposit were used to quantify the amount of deposited sediment. In addition, inflow and outflow of suspended sediment data were used to calculate the sediment-trapping efficacies (STE) of man-made SWC structures (soil bunds and fanya juu ridges) and natural sediment sinks. Results reveal that $144 \mathrm{~km}$ soil bunds and fanya juu ridges trapped $7,920 \mathrm{Mg} \mathrm{y}^{-1}\left(55 \mathrm{~kg} \mathrm{~m}^{-1} \mathrm{y}^{-1}\right)$ and micro-trenches trapped $13.26 \mathrm{Mg} \mathrm{y}^{-1}$, each micro-trench on average trapped $23 \mathrm{~kg} \mathrm{y}^{-1}$. The 17 ha floodplain located in the centre of the catchment trapped $9,970 \mathrm{Mg} \mathrm{y}^{-1}\left(59 \mathrm{~kg} \mathrm{~m}^{-2} \mathrm{y}^{-1}\right)$, while a wetland with a surface area of 24 ha, located near the outlet of the catchment, trapped $8,715 \mathrm{Mg}$ $\mathrm{y}^{-1}\left(36 \mathrm{~kg} \mathrm{~m}^{-2} \mathrm{y}^{-1}\right)$. The STEs of soil bunds and fanya juu ridges, wetlands and floodplains were $54 \%, 85 \%$ and $77 \%$, respectively. Substantial differences were observed between the STE of grassed and un-grassed waterways at $75 \%$ and $21 \%$, respectively. Existing man-made and natural sediment sinks played an important role in trapping sediment, with $38 \%\left(26,600 \mathrm{Mg} \mathrm{y}^{-1}\right)$ of transported sediment being trapped, while $62 \%\left(43,000 \mathrm{Mg} \mathrm{y}^{-1}\right)$ is exported from the catchment and thus enters the Koga reservoir. Therefore, additional catchment treatment measures are required as an integrated catchment scale sediment trapping approach to help reduce sediment loads entering Koga reservoir. Moreover, to maximize the effectiveness of sediment trapping measures, avoid structural failure and ensure their sustainability, regular maintenance is needed. Copyright () 2016 John Wiley \& Sons, Ltd.
\end{abstract}

KEY WORDS: $\quad$ soil and water conservation structures; wetland; floodplain; waterway; sediment trapping efficacy; Koga reservoir

\section{INTRODUCTION}

Soil erosion by runoff water is a global land degradation problem (Dai et al., 2015; Seutloali and Beckedahl, 2015; Stanchi et al., 2015; Novara et al., 2016; Ochoa et al., 2016). However, it is more severe in developing countries like Ethiopia (Hurni, 2000; Nyssen et al., 2004) and results in significant economic losses (Erkossa et al., 2015). Currently, water erosion is the most serious land degradation threat to the upper part of the Blue Nile basin within the north-western highlands of Ethiopia (Adimassu et al., 2014; Mekonnen et al., 2015b; Ayele et al., 2016). The main causes include erosive high intensity tropical rains, rugged topography, extensive deforestation for fuel wood, expansion of cultivation into unsuitable steeply sloping and erosion prone areas, high population pressure and the lack of integrated catchment management (Zeleke, 2000;

*Correspondence to: M. Mekonnen, Soil Physics and Land Management Group, Wageningen University, P O Box 47, 6700 AA Wageningen, The Netherlands.

E-mail: mulatiemekonneng@gmail.com
Bewket, 2002; Amsalu et al., 2007; Nyssen et al., 2004; Mekonnen and Melesse, 2011; Mekonnen et al., 2014b).

Therefore, a holistic approach is needed to tackle soil erosion in the region (Mekonnen et al., 2014b; Lanckriet et al., 2015; Nyssen et al., 2015; Tesfaye et al., 2015). Soil and water conservation (SWC) structures provide a practical means for reducing soil erosion, enhancing the rate of sedimentation and decreasing local slope gradient (Gebremichael et al., 2005; Mekonnen et al., 2015a). Various soil and water conservation measures have been implemented at large spatial scales by the Ethiopian government and international and national non-governmental organizations. For instance, $2 \cdot 1$ million ha of hillsides and farmlands were covered by SWC structures in the Amhara National Regional State from 2011 to 2013 (Engdayehu et al., 2015), and a further 1.2 million ha in 2014-2015 (BOA, 2015).

Effective sediment trapping (ST) measures can disconnect landscape units from each other, resulting in a decrease in runoff velocity and sediment transport and, subsequently, reduced downstream sedimentation impacts (Mekonnen 
et al., 2014b). This is enhanced by placing barriers and buffers in the catchment, which ultimately reduces sediment connectivity (Fryirs, 2012). According to Baartman et al. (2013), man-made structures such as terraces reduce sediment delivery to the catchment outlet. Research has shown that leaving mulch on the soil surface within the catchment can also reduce the amount of sediment being detached (Cerda et al., 2015; Keesstra et al., 2016; Prosdocimi et al., 2016).

The Minizr catchment is an important source of water for the Koga reservoir in the northwest highlands of Ethiopia (Figure 1). To trap sediment within the catchment and reduce sediment loads reaching the reservoir, considerable effort was made to implement soil bund (Erken) and fanya juu ridge (Cab) and also micro-trench structures across large sections of the catchment. Over $144 \mathrm{~km}$ of soil/stone bunds and fanya juu ridges, and $>576$ micro-trenches were constructed within the catchment. In addition, existing natural sediment sinks such as wetlands and floodplains occur over large areas of the catchment and are supplementing man-made structures in trapping sediment within the catchment (Figure 1).

Nevertheless, considerable soil is being eroded from the Minizr catchment and transported into the Koga reservoir: annually $43,000 \mathrm{Mg}$ of suspended sediment enters the Koga reservoir (Mekonnen et al., 2016). In order to reduce the sediment load through improving the sediment trapping efficacy (STE) of the SWC structures, it is important to assess the functioning and effectiveness of existing SWC structures. According to Yeshaneh et al. (2014), there is a lack of indepth studies quantifying the volume of sediment being deposited within SWC structures. Previous research demonstrates that terraces play a key role in trapping sediment and disconnecting sediment transfer pathways in a catchment, but very few have been measured (Marchamalo et al., 2016).

Consequently, the objectives of this study in the Minizr catchment, northwest Ethiopia were to: (i) evaluate the functioning and effectiveness of both man-made structures (soil bund, fanya juu and micro-trenches) and natural sediment sinks (floodplain, wetland and waterways); and (ii) quantify the amount of sediment trapped and stored in these man-made and natural sediment sinks.

\section{MATERIAL AND METHODS}

\section{Study Area}

The study was conducted in the Minizr catchment in the North-western highlands of Ethiopia (UTM 12558911249499 N; 303559-310272 E; Adindan_UTM_Zone_37N, Figure 1) which is a source of water for the Koga reservoir. It covers an area of $20 \mathrm{~km}^{2}$ with an elevation range of $2035 \mathrm{~m}$ at the outlet to $2283 \mathrm{~m}$.a.s.l. at its highest point on the watershed divide. Slopes in the catchment range from $0-51 \%$ (average of $8 \%$ ), while $>80 \%$ of the catchment has slopes between $0-8 \%$.

Average rainfall (2013-2015) was $1215 \mathrm{~mm} \mathrm{y}^{-1}$, which falls mainly between June and September, and is preceded and followed by 1 month of sporadic, low intensity rain. Average minimum and maximum temperatures are 11 and $26^{\circ} \mathrm{C}$, respectively. The dominant soil types are Nitosols (62\%), Eutric Vertisols (30\%), Lithic Leptosols (6\%) and Chromic Cambisols (2\%) (MNREP, 1995). Figure 1 shows the $144 \mathrm{~km}$ soil bund and fanya juu ridges implemented in Minizr catchment, a 24 ha wetland located near the outlet of the catchment and a small floodplain area of 17 ha located at the centre of the catchment, which help to trap sediment and reduce sedimentation of Koga reservoir. In the wetland area, Chromic Cambisols dominate. They are developed from alluvial deposits. The soil is very deep, poorly drained with a dark gray to grayish brown, silty clay loam texture, while the floodplain soil is a Eutric Vertisol which is a very deep, poor to very poorly drained, cracking heavy clay textured soil. The floodplain (Figure 1) is $696 \mathrm{~m}$ long and

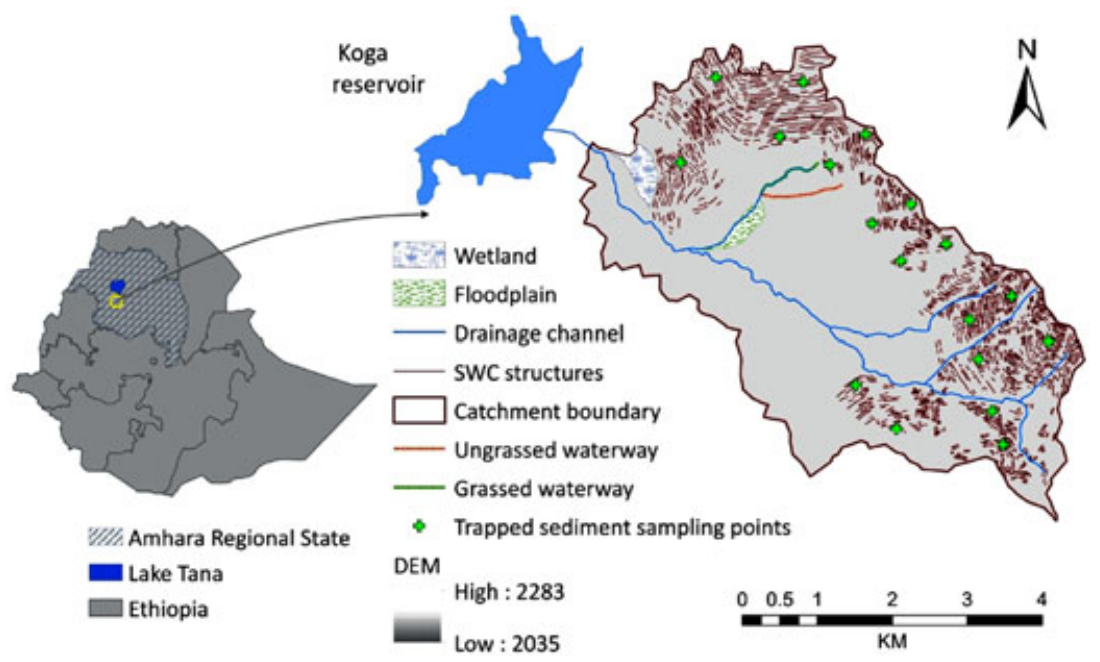

Figure 1. Location map of the Minizr catchment, in the NW Ethiopian highlands of the Upper Blue Nile basin showing the soil and water conservation structures implemented to trap sediment (soil bunds and fanya juu ridges), natural sediment sinks (floodplain, wetland and grassed waterway); and trapped sediment sampling sites. [Colour figure can be viewed at wileyonlinelibrary.com] 
$243 \mathrm{~m}$ wide and is covered with grass, which serves as a grazing area during the dry season.

Land use within the catchment area includes $71 \%$ cropping land, $18 \%$ grazing land, while plantation, bush land and settlement areas account for the remaining $11 \%$.

\section{Mapping}

All SWC structures, land use/cover, wetland and floodplain areas were digitized and mapped from Google Earth Imagery using ArcGIS 10·2 1 . A Digital Elevation Model (ASTER DEM 30m; 2009) was used to delineate the boundary of the Minizr catchment and for evaluating its elevation and slope characteristics. A GPS (Garmin 60; $2 \mathrm{~m}$ accuracy) helped to collect coordinate points and accurately geo-reference the location of rain gauges, sediment sampling sites and the catchment outlet.

\section{Measuring Trapped Sediment in Soil and Water Conservation Structures}

Three types of SWC structures soil bund (Erken), fanya juu ridge $(\mathrm{Cab})$ and micro-trenches have been widely implemented throughout the Minizr catchment (Figure 2). Soil bund and fanya juu ridges were built on farmers' fields, whereas micro-trenches were constructed on degraded grazing lands and integrated with area closures. Figure 3 shows the detailed dimensions of the soil bund and fanya juu ridge.

According to Lakel et al. (2010) and Slattery et al. (2002), sediment pins and direct measurements of the sedimentary deposit can be used to quantify the amount of sediment in the sediment sinks. In this study, sediment pins and vertical cut measurements of the deposited sediment were used to

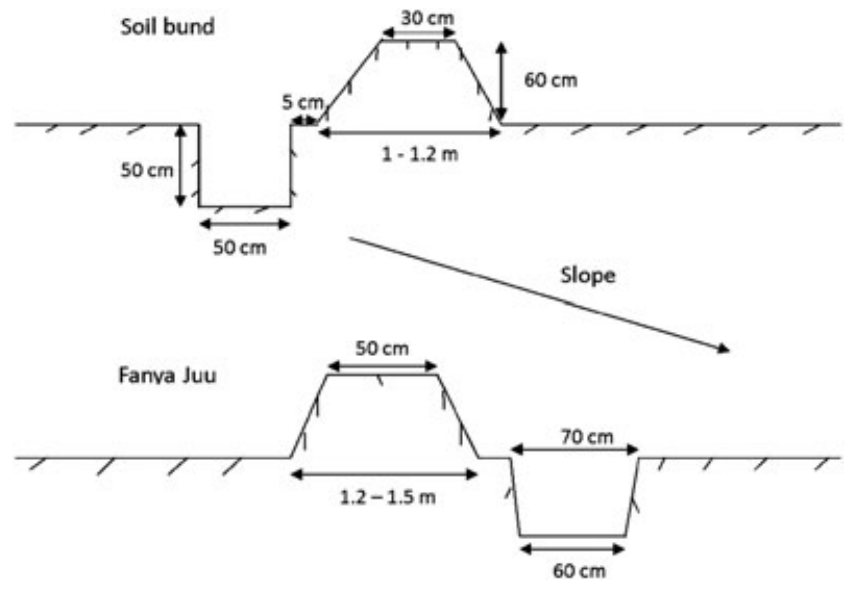

Figure 3. Schematic diagram showing a soil bund (erken; upper) and fanya juu (cab; lower) operate to trap sediment from upslope. Both of them are positioned perpendicular to the slope and runoff direction, thereby maximizing sedimentation and infiltration of surface runoff (MOAR, 2005).

measure the depth of sediment trapped by the SWC structures. Over a two-year period (2014 and 2015), a total of 214 depth measurements were recorded (72 from soil bunds; 72 from fanya juu and 70 from micro-trenches).

When selecting which soil bund and fanya juu ridge to sample, three slope classes were considered: $<5 \%$ (lower), $5-7 \%$ (middle) and $>7 \%$ (upper). Sampling sites were replicated three times for each of the three slope classes, while three soil bunds and three fanya juu ridges were also evaluated.

The deposited sediment was measured for the nine 30 meter soil bunds. Sediment depth was recorded at four

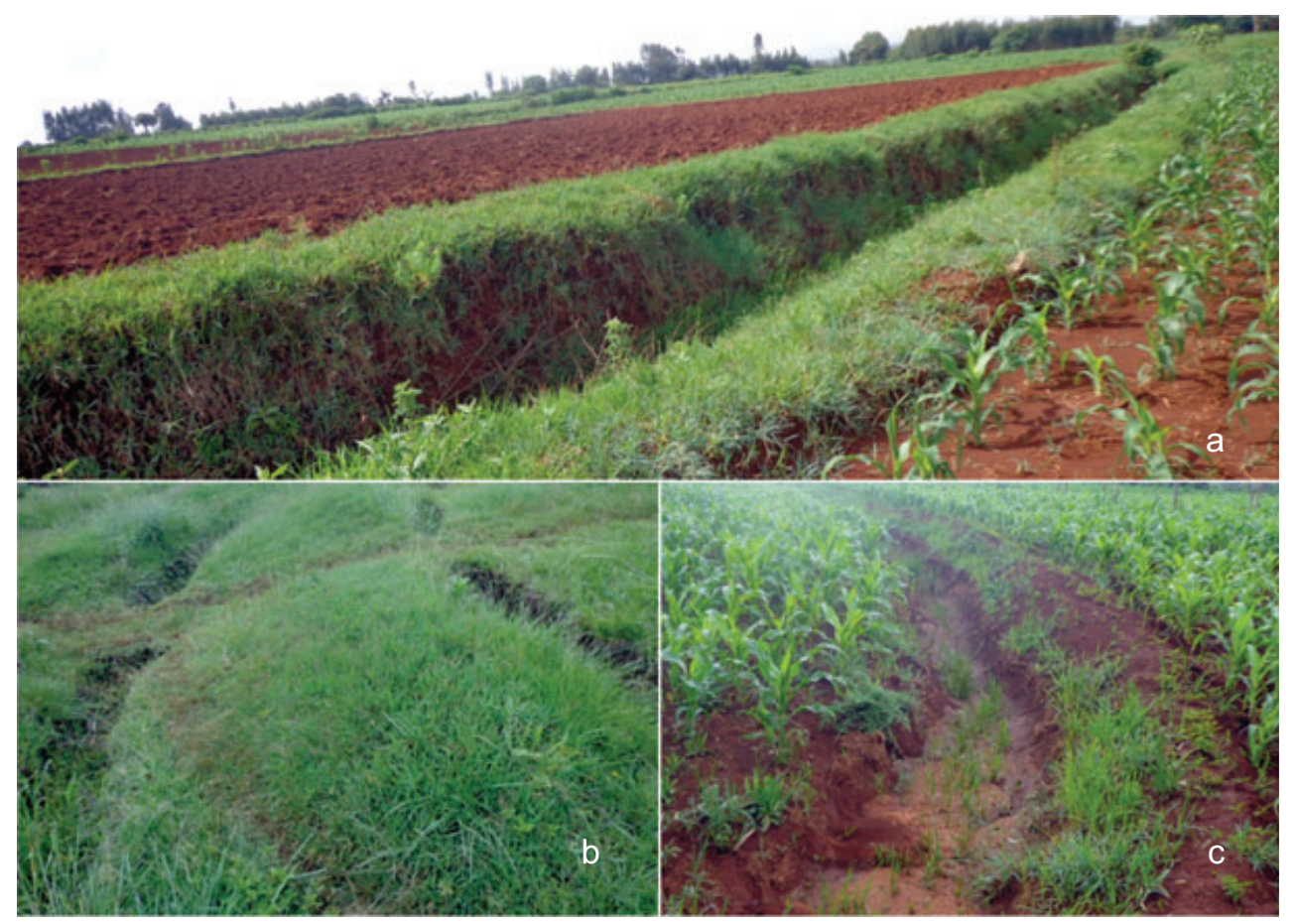

Figure 2. Sample pictures of a fanya juu (a), micro-trenches (b) and a soil bund (c) structures implemented for sediment trapping at Minizr catchment. [Colour figure can be viewed at wileyonlinelibrary.com] 
representative locations (every $10 \mathrm{~m}$ distance along each bund) resulting in 36 measurements in 2014 and 72 in 2015. Similarly, nine representative fanya juu ridges $(30 \mathrm{~m}$ each) were selected. Before the rainy season, 36 sediment pins ( $10 \mathrm{~m}$ spacing, four sediment pins per ridge) were installed, with the depth of sediment measured at the end of the rainy season in 2014 and 2015. In total, 72 depths were collected over the 2 years. Sedimentation width of fanya juu ridges ranged from $0.3-0.9 \mathrm{~m}$ with an average of $0.6 \mathrm{~m}$. In addition to sediment pins, vertical cut measurements through the deposited sediment were taken upslope of the fanya juu ridge to increase the accuracy of the data. To calculate the total volume of the trapped sediment, the average depth and width of sedimentation of the two SWC structures (fanya juu and soil bunds) were multiplied by their total length within the catchment.

A sub-catchment containing SWC structures (soil bunds and fanya juu) was selected to evaluate the STE of the structures. Sediment outflow at the outlet of the sub-catchment was measured including sediment trapped by SWC structures within the sub-catchment, which was categorized as inflow sediment. STE was calculated (Equation 1) based on sediment inflow and outflow (c.f. Verstraeten and Poesen, 2000; Mekonnen et al., 2015a) using,

$$
S T E=\frac{\left(S_{\text {inflow }}-S_{\text {outflow }}\right)}{S_{\text {inflow }}} * 100
$$

(where:) STE is sediment trapping efficacy (\%); $S_{\text {inflow }}$ is the sum of the outflow sediment measured at the outlet of the sub-catchment and sediment trapped by SWC structures $(\mathrm{kg})$, and $S_{\text {outflow }}$ is sediment measured at the outlet of the sub-catchment $(\mathrm{kg})$.

Micro-trenches on average are $1.5 \mathrm{~m}$ long and $0.4 \mathrm{~m}$ wide. Thirty micro-trenches were selected with trapped sediment depth determined by measuring the depth of micro-trenches before and after the rainy seasons in 2014 and 2015. In addition, five sediment pins were used in five micro-trenches to measure trapped sediment depth more accurately resulting in 70 sediment depth measurements. To quantify the volume of trapped sediment in a micro-trench, the average measured sedimentation depth was multiplied by the width and length of the structure, which was multiplied by the total number of micro-trenches implemented in the study area.

\section{Measuring Sediment Trapped on the Floodplain}

Sediment trapped on the floodplain was quantified using sediment pins and direct measurements of sediment depth (Riihimaki, 2011). Thirty sediment pins were installed inside the 17 ha floodplain area (Figure 1) before the rainy seasons and measured after the rainy seasons in 2014 and 2015. In addition, eight vertical cut measurements of the deposited sediment were performed every year. A total of 76 depth samples (16 direct samples and 60 buried pin depths) were taken over 2 years. To calculate the annual volume of trapped sediment, the average sedimentation depth was multiplied by the floodplain area.
To evaluate the STE of the floodplain, a total of 48 suspended sediment samples (24 composite inflows and 24 outflows in 2014 and 2015) were collected from 24 rainfall events (12 rainfall events each year). Two runoff inflow temporary streams through which the majority of the runoff enters onto the floodplain and one outflow/outlet were used to collect suspended sediment samples. The STE of the floodplain was calculated based on the measured inflow and outflow of sediment (Equation 1).

\section{Measuring Sediment Trapped in the Wetland}

Over 3 years (2013-2015), a total of 48 composite suspended sediment samples were collected at four inflow locations, while 48 samples were collected at the main outflow (16 samples each year). The reason being that runoff enters the wetland through four temporary drainage channels and exits the wetland through a single channel (Figure 4). STE of the wetland was calculated based on the measured inflow and outflow of suspended sediment (Line et al., 2008) (Equation 1).

Although suspended sediment samples were collected at the inflow and outflow points of the wetland, it was not possible to estimate the total amount of sediment that enters into the wetland because it was difficult to accurately measure and quantify the inflow runoff entering the wetland through the four temporary inflow channels. Hence, the sediment trapping inefficacy (STI) and the un-trapped sediment that passed through the wetland were used to calculate the trapped sediment contribution using Equations 2 and 3,

$$
\begin{gathered}
\operatorname{STI}(\%)=100-\operatorname{STE}(\%) \\
T S=\frac{\operatorname{STE}(\%) * U T S}{\operatorname{STI}(\%)}
\end{gathered}
$$

(where:) TS is the amount of wetland sediment trapped ( $\mathrm{t}$ ), and UTS is the amount of un-trapped sediment that passed through the wetland $(\mathrm{t})$.

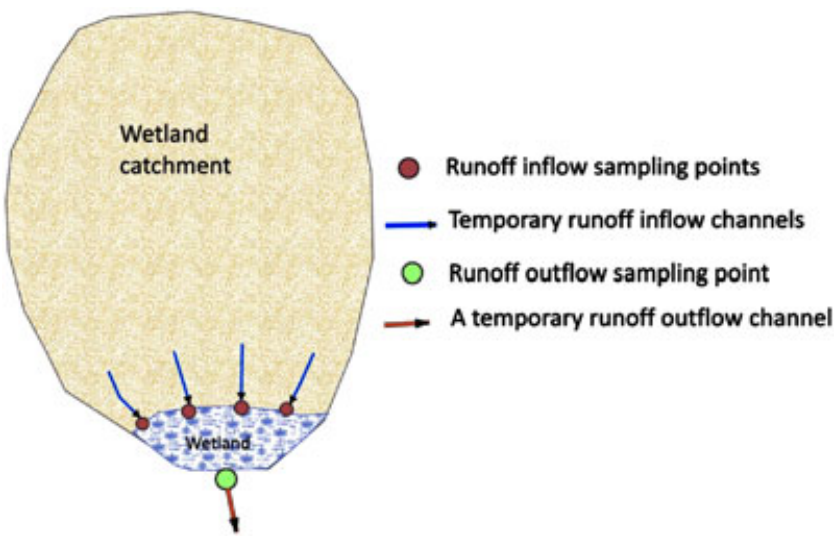

Figure 4. Schematic diagram of the wetland area showing the inflow and outflow of runoff and the locations of the suspended sediment collection sites within the Minizr catchment. [Colour figure can be viewed at wileyonlinelibrary.com] 
To quantify the un-trapped sediment that passed through the wetland, both runoff and suspended sediment data were collected at the outlet of the wetland. Runoff depth was measured using a pressure transducer (diver), while channel width was measured using a tape measure. Runoff velocity $\left(\mathrm{m} \mathrm{s}^{-1}\right)$ was measured using the Valeport 'Braystoke' Model 001 current meter. The velocity/area method (FAO, 1993) was used to estimate total runoff discharge (Equation 4), while sediment discharge was calculated from suspended sediment concentration samples (Blanchard et al., 2011) (Equation 5)

$$
\begin{gathered}
Q=A x V \\
Q_{s}=Q^{*} C_{s} * K
\end{gathered}
$$

(where:) $Q$ is runoff discharge in $\mathrm{m}^{3} \mathrm{~s}^{-1}$; $\mathrm{A}$ is channel cross sectional area $\left(\mathrm{m}^{2}\right)$ and $V$ is flow velocity $\left(\mathrm{m} \mathrm{s}^{-1}\right)$; $\mathrm{Q}_{\mathrm{s}}$ is sediment discharge $\left(t\right.$ day $\left.^{-1}\right) ; \mathrm{C}_{\mathrm{s}}$ is concentration of suspended sediment $\left(\mathrm{gl}^{-1}\right)$ and $K$ is $86 \cdot 4$, which is the conversion coefficient.

\section{Measuring Suspended Sediment in a Grassed Waterway}

Grassed waterways are areas where runoff concentrates over grassed areas rather than on bare erodible soil. Grasses enhance infiltration of the runoff and their roots bind the soil and help protect it from erosion. They also help to reduce sediment transport through decreasing flow velocity (Dermisis et al., 2010; Fiener and Auerswald, 2006; Mekonnen et al., 2015b) and are very efficient at filtering runoff and contributing to nutrient and sediment deposition. Both grassed and un-grassed waterways discharge runoff within the Minizr catchment. Therefore, two natural waterways, one covered with grass (grassed waterway) and one devoid of grass cover (un-grassed waterway) were investigated for this study.

To evaluate the suspended sediment load reduction and STE of both waterways, 60 suspended sediment samples (30 inflow and 30 outflow) were collected in 2014 and 2015 in both the grassed and un-grassed waterways with their STEs calculated using Equation 1. The grassed and un-grassed waterways were located at the outlet of two small adjacent catchments covering an area of 2.12 and $2 \cdot 18 \mathrm{~km}^{2}$, respectively. The catchments have similar rainfall, soil type, land use/cover and slope characteristics. The grassed waterway is $1023 \mathrm{~m}$ long while the un-grassed waterway has a length of $1016 \mathrm{~m}$, both with an average width ranging from 2.6-3.0 m (Figure 1).

\section{Dry Mass and Sediment Density Calculation}

To convert the trapped (deposited) sediment volume to dry sediment mass, the density of the trapped sediment was estimated using the cylindrical core method (McKenzie et al., 2002; Mekonnen et al., 2015a). Six samples from the floodplain, six from micro-trenches and 12 from SWC structures, each of $100 \mathrm{~cm}^{3}$, were collected. The samples were oven dried at $105^{\circ} \mathrm{C}$ in the laboratory for
$24 \mathrm{~h}$, with dry sediment calculated by weighing the dry sediment and subtracting it from the wet sediment mass. Dry mass of the collected suspended sediment samples at the inflow and outflow locations of the wetland, floodplain and waterways was determined in a similar manner. Density was calculated by dividing the dry sediment mass by volume.

\section{Statistical Analysis}

Data analysis was performed using Microsoft Excel and IBM SPSS statistics 22 software. ANOVA was run to evaluate differences in sedimentation rates for the different slope classes (upper, middle and lower) in the catchment and to compare the means of trapped sediment by soil bund and fanya juu ridges.

\section{RESULTS}

\section{Sediment Trapped by Soil and Water Conservation Structures}

In the Minizr catchment, there are $144 \mathrm{~km}$ of soil bunds and fanya juu ridges. Overall, the mean measured rate of sedimentation from the sampled soil bunds and fanya juu ridges was $0.053 \mathrm{~m}^{3} \mathrm{~m}^{-1} \mathrm{y}^{-1}$ or $55 \mathrm{~kg} \mathrm{~m}^{-1} \mathrm{y}^{-1}$, with an average depth of $0.09 \mathrm{~m}$. Furthermore, the rate of sedimentation was not significantly different at $p<0.05$ in the upper, middle and lower parts of the catchment and between the soil bunds and fanya juu ridges (Table I). The total annual sediment trapped was $7,620 \mathrm{~m}^{3}$ or $7,922 \mathrm{Mg}$ (using an average bulk density of $1.04 \mathrm{~g} \mathrm{~cm}^{-3}$ ), resulting in a STE of 54\%. All micro-trenches (576 in total) constructed on grazing lands trapped $13 \mathrm{~m}^{3} \mathrm{y}^{-1}$ or $13.26 \mathrm{Mg}$ $\mathrm{y}^{-1}$ (using an average bulk density of $1.02 \mathrm{~g} \mathrm{~cm}^{-3}$ ), with each individual micro-trench trapping $23 \mathrm{~kg}$ of sediment annually.

\section{Sediment Trapped on the Floodplain}

Over 2014 and 2015, the average inflow, outflow and sediment trapped by the floodplain were $15.9,3.7$ and $12 \cdot 2 \mathrm{~g}^{-1}$, respectively, with STE calculated at $77 \%$. Thus, a total of $12,950 \mathrm{Mg} \mathrm{y}^{-1}$ of soil was eroded from the upper catchment and transported onto the floodplain. On the 17 ha floodplain, $8,670 \mathrm{~m}^{3}$ or $9,970 \mathrm{Mg}$ of sediment (using a bulk density of $1.15 \mathrm{~g} \mathrm{~cm}^{-3}$ ) was trapped at a sediment depth of $5.1 \mathrm{~cm}$, and an average sedimentation rate of $59 \mathrm{~kg} \mathrm{~m}^{-2} \mathrm{y}^{-1}$. Although $77 \%$ of the inflow sediment was trapped, $23 \%$ was transported downstream through the floodplain, which amounts to $2,590 \mathrm{~m}^{3} \mathrm{y}^{-1}$ or $2,980 \mathrm{Mg} \mathrm{y}^{-1}$.

\section{Sediment Trapped in the Wetland}

In the wetland, over the 3 years (2013-2015), the average inflow, outflow and trapped sediment was 6.7, 1.0 and $5.7 \mathrm{gl}^{-1}$, respectively, with the STE of the wetland being $85 \%$. The average annual volume of sediment trapped and accumulated in the wetland was $8,715 \mathrm{Mg}$ with a 
Table I. Catchment sedimentation within a sample of fanya juu and soil bund structures

\begin{tabular}{|c|c|c|c|c|c|}
\hline \multirow[t]{2}{*}{ Structure $^{\mathrm{a}}$} & \multirow{2}{*}{$\begin{array}{l}\text { Position in the } \\
\text { catchment }^{\mathrm{b}}\end{array}$} & \multirow{2}{*}{$\begin{array}{l}\text { Sediment } \\
\operatorname{depth}^{\mathrm{c}}(\mathrm{m})\end{array}$} & \multirow{2}{*}{$\begin{array}{l}\text { Total sedimentation } \\
\qquad\left(\mathrm{m}^{3} 30 \mathrm{~m}^{-1}\right)\end{array}$} & \multicolumn{2}{|c|}{ Rate of sedimentation ${ }^{\mathrm{e}}$} \\
\hline & & & & $\left(\mathrm{m}^{3} \mathrm{~m}^{-1} \mathrm{y}^{-1}\right)$ & $\left(\mathrm{kg} \mathrm{m}^{-1} \mathrm{y}^{-1}\right)$ \\
\hline Fanya juu & Middle & 0.09 & $1 \cdot 68$ & $0 \cdot 056^{\mathrm{a}}$ & $57 \cdot 12^{\mathrm{a}}$ \\
\hline Fanya juu & Lower & $0 \cdot 10$ & $1 \cdot 74$ & $0 \cdot 058^{a}$ & $59 \cdot 16^{\mathrm{a}}$ \\
\hline Soil bunds & Upper & $0 \cdot 08$ & $1 \cdot 20$ & $0 \cdot 040^{\mathrm{a}}$ & $40 \cdot 80^{\mathrm{a}}$ \\
\hline Soil bunds & Middle & $0 \cdot 10$ & $1 \cdot 50$ & $0 \cdot 050^{\mathrm{a}}$ & $51 \cdot 00^{\mathrm{a}}$ \\
\hline Soil bunds & Lower & $0 \cdot 11$ & $1 \cdot 65$ & $0.055^{\mathrm{a}}$ & $56 \cdot 10^{\mathrm{a}}$ \\
\hline Average & - & 0.09 & $1 \cdot 60$ & 0.053 & $55 \cdot 00$ \\
\hline
\end{tabular}

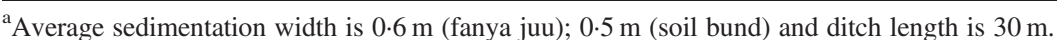

${ }^{\mathrm{b}}$ Position and slopes in the catchment; Upper ( $\left.>7 \%\right)$, Middle $(5-7 \%)$ and Lower $(<5 \%)$ slopes.

${ }^{\mathrm{c}}$ Two years average deposited sediment depth.

${ }^{\mathrm{d}}$ Two years average sediment deposited behind $30 \mathrm{~m}$ structures.

${ }^{\mathrm{e}}$ Two years average rate of sedimentation.

${ }^{\text {a }}$ Significance test of mean difference among treatments at $p<0 \cdot 05$, which shows a non-significant difference

sedimentation rate of $36 \mathrm{~kg} \mathrm{~m}^{-2} \mathrm{y}^{-1}$. The remaining $15 \%$ of the sediment or $1,540 \mathrm{Mg} \mathrm{y}^{-1}$, was annually transported downstream through the wetland. Therefore, $10,250 \mathrm{Mg}$ $\mathrm{y}^{-1}$ of soil was eroded from the upper catchment and transported into the wetland.

\section{Sediment Trapped in Waterways}

The average inflow, outflow and trapped sediment over 2014 and 2015, respectively, was 5.6, 1.4 and $4 \cdot 2 \mathrm{gl}^{-1}$ (grassed waterway) and 5.6, 4.4 and $1 \cdot 2 \mathrm{gl}^{-1}$ (un-grassed waterway); with STEs of $75 \%$ and $21 \%$ for the grassed and un-grassed waterways, respectively. The grassed waterway reduced suspended sediment content of the runoff three times more than the un-grassed waterway. This is clearly evident in Figure 5 which shows the junction between low sediment-laden runoff at the end of the grassed waterway on the left (a), and the high sediment-laden runoff at the end of the un-grassed waterway (b) on the right.

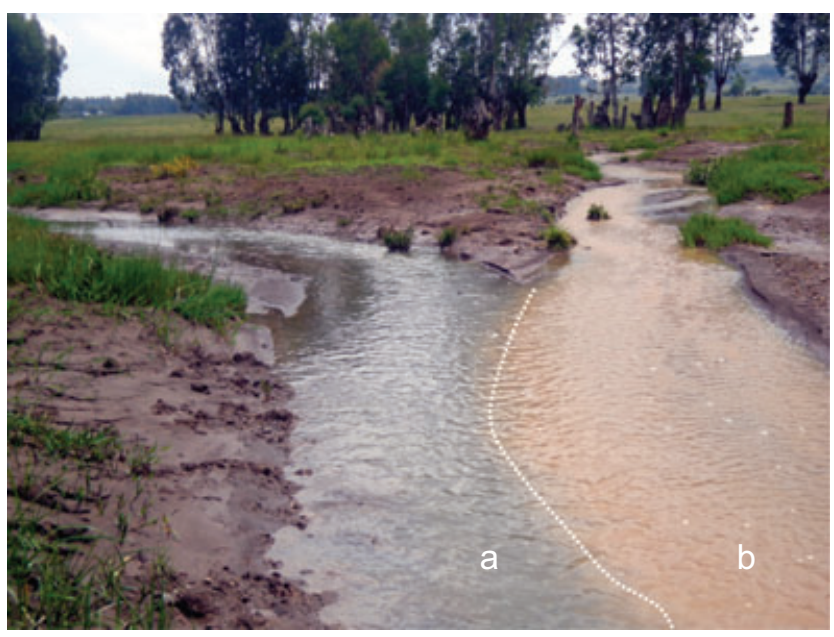

Figure 5. Difference in sediment content in the runoff is reflected in differences in sediment loads at the junction between the grassed (a) and ungrassed (b) waterways. [Colour figure can be viewed at wileyonlinelibrary.com]

\section{DISCUSSION}

Sediment Trapping by Man-made Soil and Water Conservation Structures

In the Minizr catchment, the rate of sedimentation caused by soil bunds and fanya juu ridges, was on average $55 \mathrm{~kg} \mathrm{~m}^{-1}$ $\mathrm{y}^{-1}$ with STE 54\%. This finding agrees with Lecce et al. (2006), who found drainage ditch sedimentation rates ranging from 12.5 to $88.8 \mathrm{~kg} \mathrm{~m}^{-1} \mathrm{y}^{-1}$ in North Carolina.

However, according to Gebremichael et al. (2005), in the northern part of Ethiopia (Dogua Tembien district), the rate of sedimentation behind stone bunds was $119 \mathrm{~kg} \mathrm{~m}^{-1} \mathrm{y}^{-1}$, which is much higher than the results obtained in this study. Differences in the rate of on-site soil erosion can significantly affect the inflow of sediment into the structures. Soil erosion in the Dogua Tembien district was much higher $\left(57 \mathrm{Mgha}^{-1} \mathrm{y}^{-1}\right)$ than in the Minizr catchment (21.5 $\left.\mathrm{Mg} \mathrm{ha}^{-1} \mathrm{y}^{-1}\right)$. In general, SWC structures constructed within fields were found to trap large amounts of sediment and made a major contribution to the reduction of sediment entering the Koga reservoir at the catchment outlet.

Soil and water conservation structures reduce the slope gradient of farmland by forming bench terraces as a result of sediment accumulation (Gebremichael et al., 2005; Mekonnen et al., 2015a). In the study area, even though no statistically significant difference was found in the rate of sedimentation between soil bunds and fanya juu ridges at different slopes, 20 year old fanya juu form high sediment ridge lines because the trapped sediment have gradually converted them into bench terraces (Figure 2a). This decreased average slope gradients by $2 \cdot 7 \%$. However, soil bunds do not alter the slope gradient largely because the trapped sediment is buried inside the ditch instead of forming a sediment ridge in front of the structure.

\section{Sediment Trapping - Natural Sediment Sinks}

In the study area, natural sediment sinks played an important role in trapping sediment and reducing downstream reservoir sedimentation. The 24 ha wetland located near the outlet of the Minizr catchment (Figure 1) trapped $8,715 \mathrm{Mg}$ of 
sediment annually at an average sedimentation rate of $36 \mathrm{~kg} \mathrm{~m}^{-2} \mathrm{y}^{-1}$ with a STE of $85 \%$. This result agrees well with the literature. Braskerud (2001) found for constructed wetlands in southeast Norway, sedimentation rates of 14$121 \mathrm{~kg} \mathrm{~m}^{-2} \mathrm{y}^{-1}$. Elder and Goddard (1996) obtained a STE of $80 \%$ at the Jackson Creek wetland in Wisconsin, while the Imperial Valley wetland in California had a STE of $97 \%$ (Kadlec et al., 2010). Other constructed wetlands revealed STEs of 71-90\% in southern Brazil (Sezerino et al., 2012), and 72-88\% in North Carolina (Line et al., 2008). Variations in these ranges are largely because of the natural morphology and size of the wetlands and vegetation species composition and diversity, which all have an important influence on the STE of the wetland in reducing erosion and enhancing deposition (Berendse et al., 2015; Braskerud, 2001; Mekonnen et al., 2015b).

According to Keesstra (2007) and Keesstra et al. (2009), sediment deposition on a floodplain depends on the location of the floodplain within the catchment and also on the width and land cover of the floodplain. In addition, sediment influx from hillslopes and the intensity of rainfall, all play a role in governing the potential of a floodplain or wetland to trap incoming sediment. In this study, a $696 \mathrm{~m}$ long and $243 \mathrm{~m}$ wide floodplain, which was covered with grass, trapped $9,970 \mathrm{Mg}$ of sediment annually with a STE of $77 \%$ and an average sedimentation rate of $59 \mathrm{~kg} \mathrm{~m}^{-2} \mathrm{y}^{-1}$. This result is in line with Brunet and Astin (2008), who found sedimentation rates on floodplains in southwest France ranging from $0 \cdot 02-75 \mathrm{~kg} \mathrm{~m}^{-2} \mathrm{y}^{-1}$.

Sediment load reduction in grassed waterways ranged from $65 \%$ (Dermisis et al., 2010) to 97\% (Fiener and Auerswald, 2003). In this study, sediment discharge decreased by $75 \%$ between the grassed waterway inflow and outflow. Sediment reduction was considerably higher in grassed waterways than in un-grassed waterways (21\%). In addition to trapping sediment, grass cover decreased the propensity for scour, deepening and widening of the waterway by erosion, further reducing the sediment yield from the catchment area.

Although the wetland plays an important role in trapping sediment, floodwaters will inundate the wetland, which over time, will be converted into farmland because of the persistent sediment accumulation. According to Wang et al. (2014), watershed management designed to reduce sediment input into the wetland may aid in the conservation of natural wetlands. Therefore, emphasis should be given to man-made ST measures on fields in the upper catchment to help trap and reduce sediment input into the wetland.

Agricultural expansion has also strongly affected the existence of the wetland which has been given to landless youths to cultivate and grow crops. They are slowly converting the wetland into farmland by draining the wetland water and ploughing it. This will destroy the wetland and its ecosystem in a very short period of time. As an alternative, instead of cultivating the wetland area for crop production, the youths could use the grass growing on the wetland for livestock fattening, as a means of generating income without affecting the wetland. Therefore, awareness raising of policy makers, the surrounding farmers and youth associations is needed to sustainably conserve and manage the wetland.

\section{Disconnecting Sediment Transfer Pathways}

Connectivity is an emerging issue of a catchment system (Bracken et al., 2015; Parsons et al., 2015), which indicates how well a system transfers substances, such as water and sediment, through it. The combined effect of ST measures both on-site and off-site will reduce the connectivity of the landscape and sediment transfer pathways within the catchment (Mekonnen et al., 2014b).

The possibility for sediment to be trapped within the catchment is enhanced by the appropriate placement of barriers and buffers, which can reduce sediment connectivity (Fryirs, 2012). According to Baartman et al. (2013), man-made structures like terraces are reducing sediment delivery to the outlet. Cerda et al. (2015) and Keesstra et al. (2016) have shown that leaving mulch within the catchment can reduce the amount of sediment transported to the catchment outlet. Furthermore, reducing the input of sediment from roads as a significant sediment contributor (Pereira et al., 2015) to the total sediment budget, is needed as part of an integrated approach to the whole catchment system. In addition, studies on the impact of plant species (Mekonnen et al., 2015b; Novara et al., 2013) and plant species diversity (Berendse et al., 2015), reveal that by effectively managing plant cover, sediment can be trapped more effectively and that soil erosion can be further reduced.

By utilizing scientific agricultural practices, appropriate SWC measures, and the effective management of the land with suitable plant species, sediment yield at the catchment scale can be reduced. In this study, SWC measures and natural sediment sinks (floodplain and wetland) trapped considerable quantities of sediment by disconnecting the sediment transfer paths within the catchment. SWC structures such as Fanya juu, played an important role in disconnecting the landscape by forming ridges because of the accumulated sediment, which further reduced the slope gradient.

\section{Integrated Sediment Trapping}

According to Mekonnen et al. (2014b), an integrated ST approach at the catchment scale is believed to be the most effective way in helping to increase the STE of ST measures and thereby reducing sediment loads at the outlet of a catchment. On-site ST measures can help maintain sediments on agricultural field sites, while off-site ST measures trap sediments in drainage channels and gullies. Sediments transported from farmlands without being trapped by on-site ST measures can be trapped by off-site ST measures.

In the Minizr catchment, despite the presence of numerous man-made ST structures and natural sediment sinks trapping large quantities of sediment $(26,600 \mathrm{Mg})$, this only amounts to $38 \%$ of the total sediment load, with the vast majority $(62 \%)$ being deposited in the Koga reservoir $(43,000 \mathrm{Mg})$. There are three reasons for this: 
- more emphasis is given to managing on-site sediment sources when implementing SWC structures within fields, without addressing gully erosion or riverbank erosion, which are both important sediment sources in the catchment. According to Mekonnen et al. (2014a) and Rijkee et al. (2015), river bank and gully erosion are severe and represent an important source of sediment.

- Structural SWC measures are not fully supported with vegetative measures such as grass species, which can help improve STE. To effectively trap sediment and ensure the sustainability of ST structures, it is important to combine both vegetative and structural measures (Mekonnen et al., 2014b; Nyssen et al., 2009).

- Lack of regular maintenance and free grazing are causing SWC structural failures, which affect STE and reduce the sustainability of SWC structures.

To effectively trap sediment within the catchment and further reduce sediment entering the Koga reservoir, an integrated ST approach is needed. This includes the following:

- implementing off-site ST measures such as check dams and sediment storage dams inside gullies and within drainage lines as sediment storage dams constructed inside drainage lines and gullies can trap $67-74 \%$ of incoming sediment (Mekonnen et al., 2015a),

- implementing riparian zone measures such as establishing buffer zones and planting trees along the river to reduce riverbank erosion, because vegetation causes flow retardation within the channel and on the riverbanks and thus enhances sedimentation (Keesstra et al., 2012),

- managing sediment access paths, and

- conducting regular maintenance of structures and avoiding free grazing.

\section{Using Vegetative Measures Instead of Physical Structures}

In the Minizr catchment, $144 \mathrm{~km}$ of SWC structures (fanya juu and soil bund) have been constructed in farmlands to trap sediment and thus help reduce soil loss. To construct this length of structure $69,000 \mathrm{~m}^{3}$ soil was moved from its original location either upslope (fanya juu) or downslope (soil bunds), which involved 25, 000 human labour days (work norm: 175 persons per day per km; MOARD, 2005). This process increased soil instability and facilitated soil loss, in addition to consuming large amounts of labour. To avoid this problem, vegetative ST measures were seen as better alternatives. According to Mekonnen et al. (2015b), grass barriers can trap from $20-76 \%$ of the inflow sediment on an $8 \%$ slope. Moreover, grass barriers can solve livestock feed problems, which is a crucial issue in both the study area and in Ethiopia in general.

\section{CONCLUSIONS}

The STE of existing man-made structures and natural sediment sinks were evaluated in the Minizr catchment, northwest Ethiopia. They play a significant role in trapping sediment and disconnecting sediment transfer pathways. Rates of sedimentation were $55 \mathrm{~kg} \mathrm{~m}^{-1} \mathrm{y}^{-1}$ for SWC structures (soil bunds and fanya juu), $59 \mathrm{~kg} \mathrm{~m}^{-2} \mathrm{y}^{-1}$ on the floodplain and $36 \mathrm{~kg} \mathrm{~m}^{-2} \mathrm{y}^{-1}$ in the wetland, while $>576$ individual micro-trenches can trap $23 \mathrm{~kg}$ of sediment annually. Over 20 years old, fanya juu ridges have reduced the average slope gradient by $2.7 \%$ forming lines of high sediment ridges. In soil bunds, trapped sediment is buried inside a ditch instead of forming lines of sediment ridges, which reduces its role in changing the gradient of the slope. Wetlands, floodplains, grassed waterways and SWC structures (soil bunds and fanya juu) were found to be effective sediment sinks with STEs of 85\%, 77\%, 75\% and 54\%, respectively. Despite $26,600 \mathrm{Mg}$ (38\%) of sediment being trapped by both the existing man-made structures (soil bunds, fanya juu and micro-trenches) and natural sediment sinks (wetland and floodplain), there is still $43,000 \mathrm{Mg}$ (62\%) leaving the catchment and entering Koga reservoir as suspended sediment. Therefore, additional catchment treatment measures are required as an integrated catchment scale ST approach to help reduce sediment loads entering Koga reservoir. Moreover, to maximize the effectiveness of ST measures, avoid structural failure and ensure their sustainability, regular maintenance is needed.

\section{ACKNOWLEDGEMENTS}

The author would like to thank the (Netherlands Fellowship Programme, NFP; CF Number: CF8569/2012) for its financial support and the Amhara National Regional State, Bureau of Agriculture for providing the first author with the opportunity to undertake his $\mathrm{PhD}$ research. We also would like to thank Wageningen University for providing advisory services and research facilities (data collection equipment). We would also extend our thanks to Bahir Dar Soil Laboratory Center for providing laboratory facilities. Our sincere thanks go to the farmers and field data collectors for their assistance during the field work. The comments of the two anonymous reviewers and prof. Tammo Steenhuis were greatly appreciated.

\section{REFERENCES}

Adimassu Z, Mekonnen K, Yirga C, Kessler A. 2014. Effect of soil bunds on runoff, soil and nutrient losses, and crop yield in the central highlands of Ethiopia. Land Degradation and Development 25: 554-564. DOI:10.1002/ldr.2182.

Amsalu A, Stroosnijder L, de Graaf J. 2007. Long-term dynamics in land resource use and the driving forces in the Beressa watershed, highlands of Ethiopia. Journal of Environmental Management 83: 448-459. DOI:10.1016/j.jenvman.2006.04.010.

Ayele GK, Gessess AA, Addisie MB, Tilahun SA, Tebebu TY, Tenessa DB, Langendoen EJ, Nicholson CF, Steenhuis TS. 2016. A biophysical and economic assessment of a community-based rehabilitated gully in the Ethiopian highlands. Land Degradation and Development 27: 270-280. DOI:10.1002/ldr.2425.

Baartman JEM, Masselink R, Keesstra SD, Temme AJAM. 2013. Linking landscape morphological complexity and sediment connectivity. Earth 
Surface Processes and Landforms 38: 1457-1471. DOI:10.1002/ esp.3434.

Berendse F, van Ruijven J, Jongejans E, Keesstra SD. 2015. Loss of plant species diversity reduces soil erosion resistance of embankments that are crucial for the safety of human societies in low-lying areas. Ecosystems 18: 881-888. DOI:10.1007/s10021-015-9869-6.

Bewket W. 2002. Land cover dynamic since the 1950s in Chemoga watershed, blue nile basin, Ethiopia. Mountain Research and Development 22: 263-269.

Blanchard RA, Ellison CA, Galloway JM, Evans DA. 2011. Sediment concentrations, loads, and particle size distributions in the Red River of the North and selected tributaries near Fargo, North Dakota, during the 2010 spring high-flow event. U.S. Geological Survey Scientific Investigations Report 2011-5064 27 p.

BOA. 2015. Agriculture for renaissance. ANRS green development for productivity increment and society benefit. BOA achievement report. Ethiopia. Bahir Dar 89 pp.

Bracken LJ, Turnbull L, Wainwright J, Bogaart P. 2015. Sediment connectivity: a framework for understanding sediment transfer at multiple scales. Earth Surf. Process. Landforms 8: 177-188. DOI:10.1002/esp.3635.

Braskerud BC. 2001. The influence of vegetation on sedimentation and resuspension of soil particles in small constructed wetlands. Journal of Environmental Quality 30: 1447-1457.

Brunet RC, Astin KB. 2008. A comparison of sediment deposition in two adjacent floodplains of the River Adour in southwest France. Journal of Environmental Management 88: 651-657.

Cerda A, Gimenez-Morera A, Jordan A, Pereira P, Novara A, Keesstra S, Mataix-Solera J, Ruiz-Sinoga J. 2015. The shrubland as soil and water conservation agent in Mediterranean-type ecosystems. The Sierra Enguera study contribution. In: Dykes, A.P., Mulligan, M., Wainwright, J. (eds) Monitoring and modelling dynamic environments. John Wiley \& Sons 45-59. DOI: 10.1002/9781118649596.ch3

Dai Q, Liu Z, Shao H, Yang Z. 2015. Karst bare slope soil erosion and soil quality: a simulation case study. Solid Earth 6: 985-995. DOI:10.5194/ se-6-985-2015.

Dermisis D, Abaci O, Papanicolaou AN, Wilson CG. 2010. Evaluating grassed waterway efficiency in southeastern Iowa using WEPP. Soil Use and Management 26: 183-192.

Elder JF, Goddard G. 1996. Sediment and nutrient trapping efficiency of a constructed wetland near Delavan Lake. Wisconsin: US Geological Survey.

Engdayehu G, Fisseha G, Mekonnen M, Melesse M. 2015. Evaluating technical standards of physical soil and water conservation practices and their role in soil loss reduction: the case of Debre Mewi Watershed, Northwest Ethiopia. In Landscape dynamics, soil and hydrological processes in varied climates. Switzerland, Melesse AM, Abtew W (eds). Springer International Publishing; 789-818.

Erkossa T, Wudneh A, Desalegn B, Taye G. 2015. Linking soil erosion to on-site financial cost: lessons from watersheds in the blue Nile basin. Solid Earth 6: 765-774. DOI:10.5194/se-6-765-2015.

FAO. 1993. Field measurement of soil erosion and runoff. Natural resource management and environment department. FAO Corporate Document Repository. Rome.

Fiener P, Auerswald K. 2003. Effectiveness of grassed waterways in reducing runoff and sediment delivery from agricultural watersheds. Journal of Environmental Quality 32: 927-936.

Fiener P, Auerswald K. 2006. Seasonal variation of grassed waterway effectiveness in reducing runoff and sediment delivery from agricultural watersheds in temperate Europe. Soil and Tillage Research 87: 48-58. DOI:10.1016/j.still.2005.02.035.

Fryirs K. 2012. (Dis)Connectivity in catchment sediment cascades: a fresh look at the sediment delivery problem. Earth Surface Processes and Landforms 38: 30-46. DOI:10.1002/esp.3242.

Gebremichael D, Nyssen J, Poesen J, Deckers J, Haile M, Govers G, Moeyersons J. 2005. Effectiveness of stone bunds in controlling soil erosion on cropland in the Tigray highlands, northern Ethiopia. Soil Use and Management 21: 287-297.

Hurni H. 2000. Assessing sustainable land management. Agriculture, Ecosystems and Environment 81: 83-92.

Kadlec RH, Roy SB, Munson RK, Charlton S, Brownlie W. 2010. Water quality performance of treatment wetlands in the Imperial Valley, California. Ecological Engineering 36: 1093-1107. DOI:10.1016/j. ecoleng.2010.04.028.

Keesstra SD, Bruijnzeel LA, van Huissteden J. 2009. Meso-scale catchment sediment budgets: combining field surveys and modeling in the Dragonja catchment, southwest Slovenia. Earth Surface Processes and Landforms 34: 1547-1561. DOI:10.1002/esp.1846.
Keesstra SD, Kondrlova E, Czajka A, Seeger M, Maroulis J. 2012. Assessing riparian zone impacts on water and sediment movement: a new approach. Netherland Journal for Geosciences 91: 245-256.

Keesstra SD. 2007. Impact of natural reforestation on floodplain sedimentation in the Dragonja basin, SW Slovenia. Earth Surface Processes and Landforms 32: 49-65. DOI:10.1002/esp.1360.

Keesstra S, Pereira P, Novara A, Brevik EC, Azorin-Molina C, ParrasAlcántara L, Jordán A, Cerdà A. 2016. Effects of soil management techniques on soil water erosion in apricot orchards. Science of the Total Environment : 357-366 doi: 1016/j.scitotenv.2016.01.182.

Lakel WA, Aust WM, Bolding MC, Dolloff CA, Keyser P. 2010. Sediment trapping by streamside management zones of various widths after forest harvest and site preparation. Forest Science 56: 541-551.

Lanckriet S, Derudder B, Naudts J, Bauer H, Deckers J, Haile M, Nyssen J. 2015. A political ecology perspective of land degradation in the north Ethiopian highlands. Land Degradation and Development 26: 521-530. DOI: $10.1002 / \mathrm{ldr} .2278$

Lecce SA, Gares PA, Pease PP. 2006. Drainage ditches as sediment sinks on the coastal plain of north Carolina. Physical Geography 27: 447-463.

Line DE, Jennings GD, Shaffer RM, Calabria J, Hunt WF. 2008. Evaluating the effectiveness of two stormwater wetlands in north Carolina. ASABE 51: 521-528.

Marchamalo M., Hooke J. M., Sandercock P. J. 2016. Flow and sediment connectivity in semi-arid landscapes in SE Spain: patterns and controls. Land Degradation and Development. DOI: 10.1002/ldr.2352

McKenzie N, Coughlan KJ, Cresswell H. 2002. Soil physical measurement and interpretation for land evaluation. In CSIRO Publishing. Victoria: Collingwood.

Mekonnen M, Keesstra SD, Baartman JEM, Ritsema CJ. 2014a. Sediment storage dam: a structural gully erosion control and sediment trapping measure, Northwestern Ethiopia. EGU2014 Geophysical Research Abstracts 16, 114, Austria Viena.

Mekonnen M, Keesstra SD, Stroosnijder L, Baartman JEM, Maroulis J. 2014b. Soil conservation through sediment trapping: a review. Land Degradation and Development 26: 544-556. DOI:10.1002/ldr.2308.

Mekonnen M, Keesstra SD, Baartman JEM, Ritsema CJ, Melesse AM. 2015a. Evaluating sediment storage dams: Structural off-site sediment trapping measures in northwest Ethiopia. Cuadernos de Investigacion Geografica 41 (1): 7-22. DOI: 10.18172/cig.2643

Mekonnen M, Keesstra SD, Stroosnijder L, Ritsema CJ, Baartman JEM. 2015b. Evaluating indigenous grass species as on-site sediment trapping measures, northwest Ethiopian highlands. International Conference on TROPILAKES2015, Tropical lakes in a changing environment. Bahir Dar, Ethiopia 83-83 pp.

Mekonnen M, Keesstraa SD, Baartmana JEM, Leo Stroosnijder L. 2016. Assessing the integrated sediment trapping role of man-made and natural sediment sinks, Minizr catchment, Ethiopia, European Geoscience Union General Assembly 2016, 17-22 April, 2016, Austria, Vienna.

Mekonnen M, Melesse AM. 2011. Soil erosion mapping and hotspot area identification using GIS and remote sensing in northwest Ethiopian highlands, near lake Tana. In Nile river basin hydrology climate \& water use, Melesse AM (ed). Springer: Switzerland; 207-224.

MNREP. 1995. Ministry of natural resource and environmental protection, water Resource Development Authority. Feasibility study of the Birr and Koga Irrigation project, Koga catchment and irrigation studies. Koga catchment soil map. Acres International Limited Company. Ethiopia.

MOARD. 2005. Community based participatory watershed development guideline part 1. Ministry of Agriculture and Rural Development. Addis Ababa, Ethiopia.

Novara A, Gristina L, Guaitoli F, Santoro A, Cerdà A. 2013. Managing soil nitrate with cover crops and buffer strips in Sicilian vineyards. Solid Earth 4: 255-262. DOI:10.5194/se-4-255-2013.

Novara A, Keesstra S, Cerdà A, Pereira P, Gristina L. 2016. Understanding the role of soil erosion on co2-c loss using 13c isotopic signatures in abandoned Mediterranean agricultural land. Science of the Total Environment 550: 330-336. DOI:10.1016/j.scitotenv.2016.01.095.

Nyssen J, Poesen J, Haile M, Moeyersons J, Deckers J, Hurni H. 2009. Effects of land use and land cover on sheet and rill erosion rates in the Tigray highlands, Ethiopia. Zeitschrift Fur Geomorphologie 53: 171-197. DOI:10.1127/0372-8854/2009/0053-0171.

Nyssen J, Poesen J, Moeyersons J, Deckers J, Haile M, Lang A. 2004. Human impact on the environment in the Ethiopian and Eritrean highlands a state of the art. Earth-Science Reviews 64: 273-320. DOI:10.1016/s00128252(03)00078-3. 
Nyssen J, Frankl A, Zenebe A, Deckers J, Poesen J. 2015. Land management in the northern Ethiopian highlands: local and global perspectives; past, present and future. Land Degradation and Development 26: 759-764. DOI: 10.1002/ldr.2336

Ochoa PA, Fries A, Mejía D, Burneo JI, Ruíz-Sinoga JD, Cerdà A. 2016 Effects of climate, land cover and topography on soil erosion risk in a semiarid basin of the Andes. Catena 140: 31-42. DOI:10.1016/j. catena.2016.01.011.

Parsons AJ, Bracken L, Poeppl RE, Wainwright J, Keesstra SD. 2015. Introduction to special issue on connectivity in water and sediment dynamics. Earth Surface Processes \& Landforms 40: 1275-1277. DOI:10.1002/ esp.3714.

Pereira P, Giménez-Morera A, Novara A, Keesstra S, Jordán A, Masto RE, Brevik E, Azorin-Molina C, Cerdà A. 2015. The impact of road and railway embankments on runoff and soil erosion in eastern Spain. Hydrology and Earth System Sciences Discussions 12: 12947-12985. DOI:10.5194/ hessd-12-12947-2015.

Prosdocimi M, Jordán A, Tarolli P, Keesstra S, Novara A, Cerdà A. 2016. The immediate effectiveness of barley straw mulch in reducing soil erodibility and surface runoff generation in Mediterranean vineyards. Science of the Total Environment 547: 323-330. DOI:10.1016/j. scitotenv.2015.12.076.

Riihimaki C. 2011. Methodology to predict fine sediment load reductions as a result of floodplain inundation in lake Tahoe streams. Prepared for the USDA Forest Service Pacific Southwest Research Station. Final Technical Report. Upper Truckee River. California.

Rijkee P, Keesstra SD, Mekonnen M. 2015. Low-land gully formation in the Amhara region, Ethiopia. Geophysical Research Abstracts 17: EGU2015-15827.

Seutloali KE, Beckedahl HR. 2015. Understanding the factors influencing rill erosion on road cuts in the south eastern region of south Africa. Solid Earth 6: 633-641. DOI: 10.5194/se-6-633-2015
Sezerino PH, Bento AP, Decezaro ST, Carissimi E, Philippi LS. 2012. Constructed wetlands and sand filter applied as onsite post-treatment of anaerobic effluent. Water Practice \& Technology . DOI:10.2166/ wpt.2012.047

Slattery MC, Gares PA, Philippi LS. 2002. Slope-channel linkage and sediment delivery on north Carolina coastal plain cropland. Earth Surf. Process. Landforms 27: 1377-1387.

Stanchi S, Falsone G, Bonifacio E. 2015. Soil aggregation, erodibility, and erosion rates in mountain soils (NW Alps, Italy). Solid Earth 6: 403-414. DOI: $10.5194 / \mathrm{se}-6-403-2015$

Tesfaye MA, Bravo-Oviedo A, Bravo F, Kidane B, Bekele K, Sertse D. 2015. Selection of tree species and soil management for simultaneous fuelwood production and soil rehabilitation in the Ethiopian central highlands. Land Degradation and Development 26: 665-679. DOI:10.1002/ ldr. 2268 .

Verstraeten G, Poesen J. 2000. Estimating trap efficiency of small reservoirs and ponds: methods and implications for the assessment of sediment yield. Progress in Physical Geography 24: 219-251.

Wang G, Wang M, Yuan Y, Lu X, Jiang M. 2014. Effects of sediment load on the seed bank and vegetation of Calamagrostis angustifolia wetland community in the national natural wetland reserve of lake Xingkai, China. Ecological Engineering 63: 27-33. DOI:10.1016/j. ecoleng.2013.12.004

Yeshaneh E, Eder A, Blöschl G. 2014. Temporal variation of suspended sediment transport in the Koga catchment, north western Ethiopia and environmental implications. Hydrological Processes 28: 5972-5984. DOI:10.1002/hyp.10090.

Zeleke G. 2000. Landscape dynamics and soil erosion process modeling in the north-western Ethiopian highlands. African Studies Series A 16 Geographica Bernensia Berne, Switzerland 201 pp. 